\title{
Rhetoric and realities of regional integration: Botswana SME perspectives on Southern African trade
}

\author{
A.O. Thomas ${ }^{a^{*}}$ and E. Marandu \\ a Stockholm Business School, Stockholm University, 10691 Stockholm, Sweden \\ ${ }^{\mathrm{b}}$ Faculty of Business, University of Botswana, P. O. Box 70243, Gaborone, Botswana
}

*To whom all correspondence should be addressed: aot@sbs.su.se

\begin{abstract}
Despite political pronouncements about facilitating development through economic integration of geographic regions in Africa, intra-regional trade remains limited and unbalanced. While tariff barriers have declined within Southern Africa, non-tariff trade barriers to export-import growth persist, impacting on the smaller economies. Utilising interviews with small-to-medium enterprises in land-locked Botswana, this study generated in-depth qualitative data on their experience of barriers to trading regionally. The research found that administrative procedures at the national level, ambiguity of implementation at borders and constraints on logistics constitute their most daunting impediments. Among the key imperatives then for effective regional integration and economic growth among developing countries in Africa and elsewhere are standards harmonization, regulatory streamlining, process transparency and improvement of infrastructure.
\end{abstract}

\section{Introduction}

In pursuit of sustainable development, emergent and developing countries seek to diversify their economies away from natural resources and primary industries, and consequently manufacturing for export emerges as a major policy imperative. Regional economic cooperation is invariably promoted as a means of facilitating trade among member countries, thus serving as conduit to more effective global trade. Yet the impediments to export and import seem to remain extensive and are particularly problematic for smaller member-states within any such grouping of developing and emerging economies. The extant literature suggests that whether firms engage in regional or global trade may be influenced by their perception of its viability. Hence the overarching objective of this study is to document the experience of small-to-medium enterprises with conducting intra-regional trade in the context of Southern Africa.

\section{Background and context}

The treaties of the World Trade Organization (WTO) and regional economic groupings incorporate institutional structures which prohibit or at least progressively reduce formal tariff barriers to trade. Yet if the national policy of a member country is to support domestic industry against anticipated economic detriment by imports, then implicit qualitative restrictions or non-tariff barriers (NTBs) might afford some level of protection. Although tariff barriers prove more efficient than non-tariff barriers, many governments continue to use the latter to circumvent regional and global economic treaties. Thus this research aims at investigating the impact of such barriers prevailing across the
Southern African Development Community (SADC) and Southern African Customs Union (SACU), as experienced by exporters and importers in Botswana, one of the smaller member-states of both regional groupings.

\section{Southern African customs union}

Established in 1910 and comprising South Africa, Botswana, Lesotho, Namibia and Swaziland, SACU is the oldest customs union in the world. Nominally headquartered in Windhoek, Namibia, revenue-sharing continues to be administered by South Africa, its dominant member, under agreements ratified in 1969 and 2003 (McCarthy, 2003). Among its stated agenda is integration of all member states into the global economy, thus achieving sustained economic growth in the unevenly developed SACU region.

SACU aims to achieve this growth via trade and investment liberalization within the region, including free movement of domestic products, freedom of transit, and customs cooperation. Yet this has been particularly a challenge for the smaller partners of Botswana, Lesotho, Namibia and Swaziland, collectively referred to by the acronym BLNS. While the renewed treaty in post-apartheid era provides for shared decision-making and more equitable revenue sharing, it does not adequately address issues of services, intellectual property and border transaction costs (Kirk \& Stern, 2005). The status of SACU within a much larger SADC regional group remains unclear. 


\section{Southern African development community}

Formed in 1980 during the apartheid era by the then 'Frontline States' the then-called Southern African Development Coordinating Conference (SADDC) had as its prime agenda the political liberation of and reduction of economic dependence on South Africa. Transformed postapartheid in 1992 into the Southern African Development Community (SADC), its main goals are to coordinate common economic interests by supporting trade and investment flows between their members. These now comprise Angola, Botswana, Lesotho, Madagascar, Malawi, Mauritius, Mozambique, Namibia, Swaziland, Tanzania, Zambia, Zimbabwe, Congo (DRC) and South Africa, the last of which remains the dominant economy of the region, if not the whole of Africa.

Trade in goods and services and the enhancement of crossborder-investments were major areas of cooperation spelt out in the SADC Trade Cooperation Protocol signed in 1996. An official review (TIPS \& AusAid, 2007) confirmed that nontariff barriers (NTBs) were still used around the SADC region, acting as instruments of protectionism, and thus negating ambitions of fostering freer trade among the countries. Nonetheless SADC inaugurated a Free Trade Area in 2008 and had ambitious aims of a Customs Union by 2010 which has not been instituted (SADC, 2014). It also proposed a Common Market by 2015, a Monetary Union by 2016 and common currency by 2018 , all of which have not been on track for implementation.

\section{Botswana political economy}

Previously a British protectorate, Botswana gained its independence in 1966, an event which fortuitously coincided with the discovery of diamonds on its territory. Thus its GDP has grown on average at 9 percent annually in the decades since. Botswana is often lauded as the least corrupt country in Africa and ranked 28th on Transparency International (2015) Index, ahead of some Southern European countries. It is also deemed one of the more competitive economies on the African continent - in fourth place after Mauritius, South Africa and Rwanda - and with a global ranking of $74^{\text {th }}$ (World Economic Forum 2014). Nonetheless Botswana's trade potential is constrained by being a landlocked country with South Africa to its south, with Namibia to its west, Zimbabwe to its east and Zambia to its north.

While Botswana's economic performance is based on successful exporting, this is dominated by diamonds, which accounted for about 89 percent of exports in late 2013 (Figure 1). Yet this raw commodity is vulnerable to fluctuations in world demand and thus market prices for precious stones, as demonstrated during the global economic crisis in the late 2000s. Consequently there is an acknowledged need to diversify the export base to reduce over-reliance on a single non-renewable resource which naturally will be exhausted over time. Currently there is heavy dependence on imports for a wide range of mostly manufactured goods, much of it from or through South Africa (Figure 2). In order to achieve sustainable economic development, diversification of both the export and import sectors, through reduction of tariff and nontariff barriers to trade in conjunction with its regional economic agreements, has been a pertinent policy imperative for Botswana (Malefane, 2015). Yet the realities of conducting trade within the Southern African region remain fraught with challenges especially for small-to-medium enterprises within the relatively minor economy of this landlocked country.

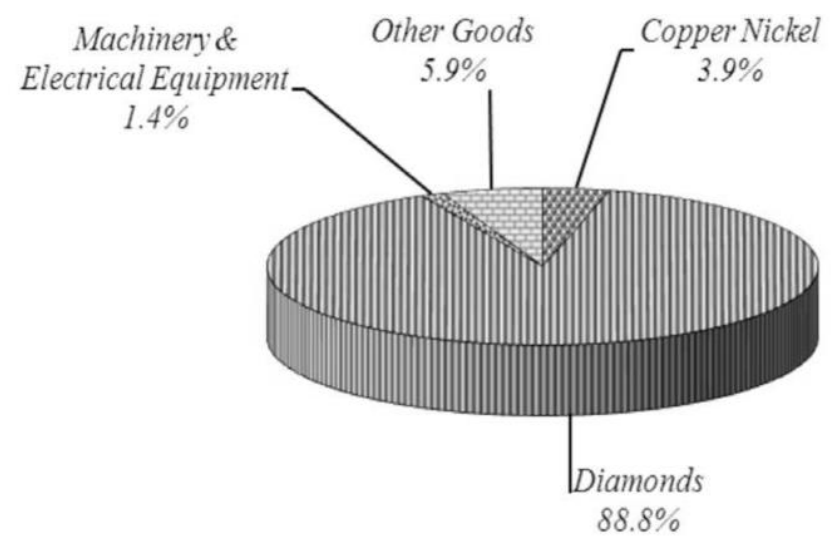

Figure 1: Botswana exports composition-Nov. 2013

Source: Statistics Botswana

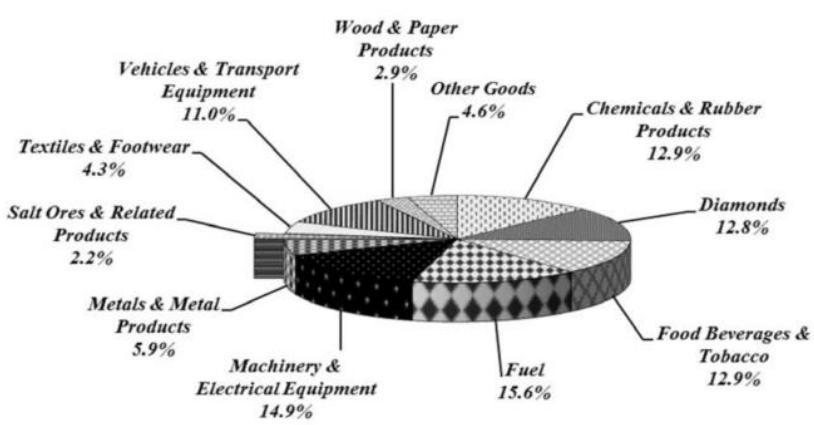

Figure 2: Botswana imports composition-Nov. 2013

Source: Statistics Botswana (2014)

Data on exports and imports between SACU and SADC member states are limited, illustrating their relative economic insignificance. In a trade matrix for the year 2013 constructed from the Botswana Bureau of Statistics (2014) data, the percentage of global imports into Botswana were substantially from or via South Africa at 70.07 percent and from all of SADC including South Africa only marginally higher at 72.08 percent (Table 1). On the other hand, almost all exports were to countries beyond Africa and these amounted to five times the quantum of total exports to the region. This considerable imbalance represents the dominance of the diamond industry in Botswana's international trade and the role of multinational corporations in it. 
Table 1: Botswana exports and imports with SACU and SADC Regions 2013

\begin{tabular}{|c|c|c|c|c|}
\hline Trade Partner & Total Imports (Pula) & \% World Imports & Total Exports (Pula) & \% World Exports \\
\hline Lesotho & 61,819 & $0.09 \%$ & 12,402 & $0.02 \%$ \\
\hline Namibia & $6,511,761$ & $9.48 \%$ & $1,847,831$ & $2.77 \%$ \\
\hline Swaziland & 33,105 & $0.48 \%$ & 9,754 & $0.01 \%$ \\
\hline South Africa & $41,520,471$ & $60.44 \%$ & $7,181,598$ & $10.75 \%$ \\
\hline SACU Total & $48,127,157$ & $70.07 \%$ & $9,051,586$ & $13.55 \%$ \\
\hline Angola & - & - & 16,392 & $0.03 \%$ \\
\hline Congo DRC & - & - & 47,770 & $0.07 \%$ \\
\hline Mauritius & 168,387 & $0.24 \%$ & - & \\
\hline Malawi & 50,524 & $0.07 \%$ & 14,914 & $0.02 \%$ \\
\hline Mozambique & 25,388 & $0.04 \%$ & 33,939 & $0.05 \%$ \\
\hline Tanzania & 1,337 & $0.002 \%$ & 12,946 & $0.02 \%$ \\
\hline Zambia & 168,065 & $0.25 \%$ & 377,858 & $0.56 \%$ \\
\hline Zimbabwe & 307,880 & $0.45 \%$ & $1,078,480$ & $1.61 \%$ \\
\hline Other SADC & 663,883 & $0.96 \%$ & 195 & - \\
\hline SADC Total & $49,512,617$ & $72.08 \%$ & $10,634,083$ & $15.92 \%$ \\
\hline AFRICA Total & $49,540,490$ & $75.40 \%$ & $10,653,571$ & $15.95 \%$ \\
\hline WORLD Total & $68,685,907$ & $100.0 \%$ & $66.790,442$. & $100.0 \%$ \\
\hline
\end{tabular}

Source: Compiled from Statistics Botswana (2014) data

\section{Reviewing the literature}

\section{Regional integration}

According to customs union theory historically, economic gains are said to emerge from specialization, economies of scale, increase efficiency through competition (Lipsey, 1987). While this has been the impetus for the formation of regional economic groupings, the evidence suggests that, as with other traditional trade theories, it has limited relevance to developing countries. Quite apart from infrastructure investment and resource development requirements, Robinson (1996) argues that effective regional integration in Africa would demand that a high price be paid by member states, namely the measurement of gains, equitable redistribution, compensation mechanisms and some relinquishing of national sovereignty.

Gravity-model research on intra-Africa trade by Longo and Sekkat (2001) points to infrastructure deficiencies, currency non-convertibility and political stability as major obstacles. Likewise, Limao and Venables (2001) demonstrate that poor infrastructure contributes 40 percent towards transport costs for coastal countries but up to 60 percent in the case of landlocked countries, the latter a finding pertinent to Botswana. As Clarke (2005) demonstrates, African manufacturers in countries that have trade restrictions, cumbersome regulations and deficient customs administration, tend to be unlikely to export. Subsequent research by (Yang \& Gupta, 2007) continues to identify high border costs, poor transport infrastructure, small market size and limited resource complementarities as limiting intra- and inter-regional trade in Africa.

\section{Economic divergence}

Much of the theoretical foundation behind studies of regional economic integration is predicated on there being mutual advantage in reciprocal trade within the region of specialized goods and services. On the basis of research on Austria, Baldauf et al (2000) argue that firm size, management orientation towards internationalisation and differentiation strategy were best predictors of export performance. But this is often not true for developing countries especially, as much of their trade volume is in raw materials or commodity goods to developed countries, for finished goods and services in return. Botswana is a case in point, with its export by far being diamonds to the developed world, competing with other countries in the region in international markets. While its primary export is of such high value-to-weight ratio to justify airfreight overseas, most other imports and exports have to be by land and via another member-nation. Their similar primary products are not able to achieve economies-of-scale and are thus seldom competitive even in the regional market, let alone international markets. Peripheral and smaller member-states of regional groups are further disadvantaged when there is a major economy dominating the regional grouping.

Reviewing the challenges of regional economic integration in Africa, Geda and Kibret (2008) group these into issues of approaches and issues of implementation. Utilising the Common Market for Eastern and Southern Africa (COMESA) as their case study and applying the gravity model, they suggest that regional groupings and drastic reductions of tariffs have had insignificant effect on bilateral trade. They argue that secretariats such as SADC lack the legislative power to require member-countries to implement treaty obligations such as macro-economic policy coordination and tariff reductions. Where tariff barriers are reduced by economic liberalization, non-tariff barriers have surfaced. Since revenue from tariffs is a significant source of 
government revenue, the short-term loss is not often relinquished for long-term benefits of regional economic integration as is the case in East Africa (Ronge, 2000). Thus Southern African nations need to learn from that experience and adopt policies that recognize the inequities of size and development of the economies within their groupings.

\section{Trade constraints}

Impediments to trade can come disguised in different forms, ranging from domestic regulations that impede market access to logistical challenges of moving goods across regions. In an early review of the literature on impediments to exporting and importing, Korth (1991) classifies these into internal and external forms.

\section{External barriers}

Generally these impediments originate in both the home and host environments in which the importing and/or exporting firms operate (Leonidou, 2004). Common trade impediments include tariffs, quotas, subsidies, domestic content requirements, transportation lack and strong currencies (Lages, 2000; Azzi da Silva \& Da Rocha, 2000) can add costs to products. Concurrent with the reduction of tariffs imposed by the World Trade Organization (WTO), the use of nontariff barriers (NTBs) has increased from $55 \%$ of all trade restrictions in 1994 to $85 \%$ in 2004; giving an average tariff equivalent of about $40 \%$ in 2004 (Kee, Nicita \& Olarreaga, 2009). However the existing literature tends to have an allencompassing definition for NTBs as almost every tradedistorting measure, apart from tariffs (Pasadilla \& Liao, 2007). Such open-ended definition implies that NTBs may include a plethora of policies that alter the prices or quantities of trade (Deardorff \& Stern, 1998).

\section{Internal impediments}

These impediments constitute factors that corporate management has direct control over but fail to perform effectively. Among other challenges historically identified by research are the firm's inability to meeting importers' quality standards (Dichtl, Koglmayr \& Muller, 1990), poor organizational structure (Yang, Leone and Alden, 1992), lack of competent personnel (Yaprak, 1985), and inadequate financing of exports (Weaver \& Pak, 1990). Although internal factors are quite fragmented, taken together these constitute issues within exporting firms which can play an inhibitory role in their ongoing export activities (Katsikeas \& Morgan, 1994). A subsequent study suggests that the number of perceived impediments to export-import may be more extensive in a relatively under-developed country environment (Ali, 1998).

\section{Framework for research}

Most impediments to trade are implicit and thus not formally documented as government regulations and are thus difficult to identify. Nonetheless the lack of transparency in the procedures and inconsistent implementation of regulations would constitute the greatest impediments to trade. Just as prior studies have demonstrated (Sazanami, Urata \& Kawai, 1995; Winkelmann \& Winkelmann, 1998), more recent reports have confirmed (Hasse 2012, Gajdos 2013), that nontariff barriers (NTBs) often inflict much greater economic loss than formal tariff barriers, especially for smaller economies. The impact of such non-tariff barriers on import and export within the Southern African region uncovered in this research could prove enlightening for other regional groupings comprising developing countries, particularly of uneven economic development.

Research on impediments to trade is timely given the policy rhetoric in recent decades of facilitating exports and imports, both globally and regionally. Since tariffs have been reduced under the World Trade Organization (WTO) and given the dominant role of regional economic groupings in the developed world such as the European Union (EU) and the North American Free Trade Area (NAFTA), and in the developing world such as Mercosur and ASEAN, interest has shifted to understanding the extent to which non-tariff barriers (NTBs) may distort and restrict trade. The increasing use of NTBs may also be related to the growing importance of service trade, where border controls such as tariffs and quotas are generally not applicable (Ching, Wong \& Zhang, 2004). The present research seeks to understand how such impediments to trade operate and are experienced by importers and exporters on the ground.

\section{Research methodology}

\section{Qualitative approach}

Much research conducted on regional trade has tended to be quantitative in nature, including in the context of Southern Africa (TIPS \& AusAid, 2007; Marandu, Phambuka-Nsimbi $\&$ Thomas, 2012). The present research aims to be analytical and in-depth given there is limited prior knowledge about the phenomenon being studied. Adopting a qualitative approach affords multi-faceted investigation of the phenomenon of trade impediments, their complexity and inter-relationships at the grass-roots level. It thus seeks to establish inductively the various impediments to intra-regional trade as articulated by key respondents in import-export oriented businesses. The research design involved semi-structured interviews supplemented by on-site observation, framed by propositions drawn from the literature review.

\section{Participants' selection}

The involvement of a majority of firms and their executives in this research was coordinated via the Botswana Exporters and Manufacturers Association (BEMA) and the defunct Botswana Export Development and Investment Agency (BEDIA), currently replaced by Botswana Investment and Trade Centre (BITC). Given their mandates to promote trade, both organizations were consulted before initiating this research project and cooperated in the data-gathering. Further interviews were done by 'cold-calling' firms in towns visited or as opportunities presented themselves while 
conducting observations at the border-posts. Thus data was obtained principally from persons involved directly in various aspects of export-import in the selected firms.

\section{Industry and firm size}

The barriers to trade tend to be perceived quite differently by firms in various industries, and their consequences rather different for firms of different sizes even within the same industry. Hence the researchers used judgment sampling to select a diversity of industries involved in import and export e.g. agriculture, retailing and manufacturing, and then a range of small and medium-sized locally-owned firms (Table 2) since these tend to be more challenged by trade barriers than larger regional or multinational corporations.

\section{Personal interviews}

The methodology of personal interviewing was chosen on two grounds. First, this approach was more likely to improve the response rate, as people feel a greater obligation to respond when face-to-face. Second, the unstructured portion of the interviews with company executives afforded insights into issues unanticipated by the study design. The interviews were conducted at the offices of the firms either by both of the authors or by one author assisted by a research associate with facility in the local language, as appropriate. Anonymized quotes from these interviews are provided in support of the data analysis made.

\section{Respondents' identification}

While the present researchers sought to interview persons holding different functional roles in firms from similar industries for more balanced opinions, most often the seniormost executives chose to represent their organizations solely or with some consultation with their subordinates. Arguably their perspectives as research respondents were a composite of the various functional areas related to regional trade, such as production, logistics, marketing and distribution, over which they had managerial oversight.

\section{Data collection and analysis}

The choice of the towns in Botswana where the study was conducted was based on either their industrial importance, proximity to border-posts, or both, because many exporters and importers are located or operate there. Gaborone was an obvious choice, being the business capital and administrative focal point of the country. Francistown was selected based mainly on its status as the second-largest city and industrial centre, but also for having a border-post nearby with Zimbabwe, another SADC member. Using the criterion of proximity to border-posts, four smaller towns were included: Ramotswa, Lobatse (near South Africa), Gantsi (near Namibia), and Selibe-Phikwe (towards Mozambique). Thus interviewing some traders at or businesses located close to the border posts was supplemented by first-hand observation of border formalities and the through-flow of import and export activities.
The analysis adopted a general inductive approach advocated by Thomas (2006) which involves a systematic research process for generating insights, yet is more streamlined than other qualitative research processes such as Grounded Theory. Accordingly all interviews were recorded, transcribed and then text fragments were assigned to already existing and newly arising categories utilizing the qualitative data analysis software NVivo. Drawing on the Thompson (1997) hermeneutic, after each single interview was coded it was compared and combined with identified patterns of the other interview. In keeping with the Rubin and Rubin (2005) guidelines, concepts presented in the theoretical framework were refined as necessary as fresh insights were identified from the data. Although seemingly time-consuming and costly, this approach generated thick descriptors from and invaluable insights into socially-constructed phenomena of managerial experience of regional trade.

\section{Table 2: Industry interview respondents}

\begin{tabular}{l|l|l|l}
\hline Organization & Industry & Size & Respondent \\
\hline Manufacturer01 & Textile & Medium & Owner \\
\hline Manufacturer02 & Bedding & Medium & Owner \\
\hline Manufacturer03 & Agribusiness & Large & $\begin{array}{l}\text { Managing } \\
\text { director }\end{array}$ \\
\hline Manufacturer04 & Textile & Large & Chairman \\
\hline Manufacturer05 & Textile & Medium & Owner \\
\hline Manufacturer06 & Textile & Micro & Owner \\
\hline Manufacturer07 & Bedding & Large & Manager \\
\hline Retailer01 & Kids Products & Small & Owner \\
\hline Retailer02 & General goods & Medium & Store manager \\
\hline Retailer03 & Fabrics & Small & Owner \\
\hline Retailer04 & Car dealer & Small & Partner \\
\hline Retailer05 & Furniture & Medium & Executive \\
\hline Wholesaler01 & Agriculture & Large & $\begin{array}{l}\text { Managing } \\
\text { director }\end{array}$ \\
\hline Wholesaler02 & General trader & Micro & Owner \\
\hline Wholesaler03 & Novelties & Small & Managing partner \\
\hline Logistics01 & Freight-forwarder & Medium & Owner \\
\hline Logistics02 & Freight-forwarder & Medium & CEO \\
\hline Logistics03 & Freight-forwarder & Small & General manager \\
\hline Logistics04 & Freight-forwarder & Medium & CEO \\
\hline Logistics05 & Clearing agent & Small & Manager \\
\hline Logistics06 & Clearing agent & Large & Senior executive \\
\hline
\end{tabular}

\section{Experience of regional trade}

\section{Markets distortion}

\section{Products and sourcing}

The importers were quite matter-of-fact about limiting the sources of their supplies for various goods and materials according to where these were readily available. While reasonable quality was an unspoken factor in demand, there was often an underlying rationale of cost-effectiveness.

"The branded ones (appliances) we get from South Africa but we have some Chinese things also." [Retailer06]

"We mainly help importers of second-hand cars from Japan, Singapore and China". [Logistics04] 
“...from Zimbabwe to Botswana they (clients) are moving plenty of timber- normally most of the timber is to hardware stores..." [Logistics06]

Overwhelmingly the sourcing was done from South Africa out of necessity and the trend was said by respondents to be increasingly so, even if just as an intermediary. This practice was often attributed to transportation or customs-clearing issues which had obvious financial and operational implications for their businesses:

"It is easy to buy the same material (from Asia) in South Africa due to less transportation costs and minimal deliveries." [Manufacturer05]

"Most of the products, $70 \%$ or almost $90 \%$ of what we import in terms of agriculture is from South Africa. We do get some certain things from India, Brazil and East Africa." [Wholesale distributor01]

"Previously we attempted to import directly from the Far East but it was too problematic. Now we prefer to use wholesalers in South Africa... though $90 \%$ of the textiles originate from Far East, particularly China.” [Retailer03]

\section{Destinations and opportunities}

Exports were less reported on by the knowledgeable respondents, except by clearing agents at the borders. When exports were mentioned, these were only as short-term opportunities due to economic conditions in neighbouring countries, particularly of Zimbabwean in the mid-to-late 2000s:

"From here we are exporting plenty of salt from the Salt Pans for both industrial and consumer purposes... going to Zimbabwe”. [Logistics06]

"When things were bad that side [Zimbabwe] people came for groceries in large quantities". [Logistics06]

"Zimbabweans want many things...groceries... they are buying cars this side... and many other things." [Logistics05]

\section{Tariff persistence}

Resentment was expressed at the continuing existence of tariff barriers imposed by South Africa and the withdrawal of previously duty-free-status elsewhere within the Southern African region, both constraining sourcing.

"We started in 1991 with manufacturing towels with yarn imported from Zambia which was then duty-free if used for own manufacturing, but this was withdrawn because of South African pressure." [Manufacturer04]

"Around 1998 I used to buy original cotton in Zimbabwe but we were charged customs duties at the border." [Manufacturer06]
There was, however, some grudging acknowledgement by respondents of the need to pre-empt dumping by foreign firms. Still they expressed disenchantment about the impact of these broad-brush measures on their own local businesses:

"South Africans do not like China... they dump their stuff there. That's why the customs duties are so expensive". [Distributor03]

"Chinese and Pakistani traders under-declare value and so avoid VAT. They also re-sell second-quality or overruns here." [Manufacturer04]

"SACU members Swaziland and South Africa have sugar. So sugar should not be coming from other countries." [Wholesaler04]

\section{Technical restrictions}

\section{Health and safety standards}

Among the most frequently cited non-tariff barriers were those that related to health-and-safety standards. Respondents were often suspicious of the extreme lengths to which these were taken and quite arbitrarily:

"That (house-) fly does not exist in this country and South Africa are sure that it doesn't exist... but they did not want us to export our melons to America." [Wholesaler04]

"Well if there is foot-and-mouth outbreak, nothing moves. But you get the issue where they say Botswana (cattle) is affected... but South Africa cattle are not." [Manufacturer03]

"...these (Botswana standards) are comparable but if South Africa realizes that whatever is imported or exported has impact on their market they change." [Wholesaler01]

While the rationale for these practices was sometimes appreciated by the industry executives, it did not detract from decrying the implications for their businesses of cost, even losses, stemming from complicated procedures:

"We have had situations where the goods are not of phyto-sanitary standard; they are sent back and you get the refund in VAT but someone has to suffer because you don't get refund on transportation." [Logistics06]

"From that end they ring us and say, your products are not certified or they are not fit for human consumption, then they must be recalled or withdrawn from the shelves if that is the case." [Manufacturer03]

\section{Questionable controls}

Quite apart from the situation in a crisis, the routine process of getting permits and testing done was quite tedious, and actually redundant. Given the compatibility 
of standards in the region, respondents complained about the non-reciprocity involved:

"That milk has to be tested in a laboratory there and then brought into this country; it has to be tested again here in the laboratory before it's produced." [Manufacturer03]

"We had some airfreight coming from China in transit via Johannesburg. And they wanted to take it for quality control - and I can't see what that has got to do with Botswana." [Logistics03]

"This commodity as it enters South Africa, it must be certified free of those diseases and pests. Yet when we import from them, we don't impose those restrictions..." [Wholesaler01].

Another complaint of managers was that the major trading partner-nation of South Africa tended to be vague about its regulatory standards which were applied quite inconsistently. These standards were also said to change arbitrarily, often at short notice and without recourse to appeal:

"They have now changed the laws and say you can't clear for yourself even if you know what to do! It's got be a South African agent clearing there.” [Manufacturer07]

"Well, you have to get multiple permits from the veterinary... So you register them, give to the driver... when you finish those you must re-apply." [Manufacturer03].

"No, duties are not really standard, there is a variation... if they (South Africa) have plenty of stuff, they tend to charge high duties so that they can market their own stuff locally..." [Logistics06]

\section{Multiple permits}

The non-standardization of licenses, permits, visas and other regulatory requirements was often raised as a concern by industry executives. Though an issue with South Africa as major trading partner, it was far from exclusively so:

"There are huge costs in exporting to Zambia and Zimbabwe because the requirement to have several permits. If a common permit is not possible then we would not mind if the costs were reasonable." [Manufacturer02]

"Yes they call it the Botswana-Zimbabwe trade agreement and there is also a Zimbabwe-Namibia trade agreement - eventually you realize that at the end of the day those agreements are more binding than SADC." [Logistics06]

\section{Administrative red-tape}

\section{Documentation complexity}

Due to the large number of forms to be filled and checked, importers and exporters face much delays in time. Furthermore serious costs are entailed if these have mistakes, however innocent:

"Yes there were fined on the wrong documentation and sometimes they say we are going to fine you R6,000 and then you negotiate R2,000. Just imagine your truck is standing with the load to go." [Manufacturer01]

"For importing into Botswana, SA form is filled, stamped and left there and then you fill Botswana form. An agent has to do it ... Trucks are standing there for one day for everybody." [Manufacturer06]

While up-to-date data-processing systems have been installed at the border to ease the process, the human resources element in implementation is a source of much frustration:

"Sometimes the staff are very helpful but at other times, such as on Friday afternoon when they want to go home early and are in no mood to work - e.g. playing card games on computers". [Logistics01]

"In a day one hour it (computer system) is fine, after that it's down. We have a type of goods, perishables that do not allow to be here for quite a long time". [Logistics06]

A notable view among respondents was that delays by border officials for seemingly mundane reasons have extremely serious implications for the traders in terms of disruptions to production operations:

"We get our timber supplies from Zim(babwe)...Sometimes he faces delays at the border that in turn causes delays operations of the company." [Manufacturer02]

"Recently we started importing processed honey from Zambia... We were stopped at the border on account that we must get an agricultural permit. But the Ministry of Agriculture there said they don't issues such permit because this is a processed product." [Manufacturer03]

\section{Arbitrary taxes}

One major issue raised by the research respondents was the complexity of VAT administration of countries within the region which has to be paid upfront even for goods in transit through one country to its destination:

"Our suppliers in SA, by law, must charge VAT and we can reclaim it when goods cross the border. However the process is long and it may take up to six months... This ties down our capital." [Manufacturer07] 
"In Zimbabwe they have their valuation standards... If ever you have got a car from Singapore that you bought for R3,000, they will value it according to the value they have got." [Logistics05]

Although resigned to having to pay VAT, the importers and exporters saw this tariff barrier as also a non-tariff one, discouraging trade. The slow refund ties up capital, not to mention the risk of drivers to having to carry large amounts of cash:

"They [duties] all vary, there is a huge tariff book, hundreds of pages... Whatever comes into that (SACU) pays the same duty but within the borders only the VAT." [Wholesaler02]

"Actually returning goods that wasn't properly done or was wrongly order - to take it back costs more than to even buy it..." [Wholesaler03]

"So if I am sending six or seven trucks on Monday, I should give them somewhere in R80,000 in cash (US\$10,000) for the VAT." [Manufacturer07]

\section{Penalty costs}

Not only is there a need for multiple permits, licenses and visas, but the failure to hold valid ones can prove very expensive in terms of penalties and therefore are perceived also as trade barriers:

"SA require the export permit and that permit they [farmers] have to pay. If the importer does not have that export permit at the border he is heavily charged... Yes, like a fine." [Wholesaler01].

" But there is something called a bond... The chances of Zimbabwean truck being sold here are nil because they have to follow the Interpol clearance but you find that these are just barriers." [Logistics06]

"When cars reach Durban, they are expected to be out of the bonded warehouses within three days, heading for their destination, or else they are charged R20,000 per day." [Logistics04]

On the other hand the urgent need to renew permits, licenses and visas frequently is reported by respondents to be highly problematic and costly in terms of time as well in terms of having to travel long distances to meet compliance requirements:

"In Zimbabwe drivers have to go for a re-test and sometimes you can even fail - the company and the driver is fined and then a new driver must come to take the truck and continue with the journey." [Logistics06]

"SACU truck permit expires after every three months... So every three months with 9 trucks and 9 trailers you have to go to South Africa for inspection and renewal." [Manufacturer02]

"So wherever the drivers are, they have to drive all the way to Pretoria and apply for that permit. And for 3 months depending they have to pay R380." [Wholesaler01].

\section{Compliance monitoring:}

\section{Police interventions}

Added to that are the systematic scams involving the rerouting of goods after declaring a false destination in order to avoid paying higher tariffs. This in turn results in greater vigilance by the authorities, affecting legitimate traders:

"There is a lack of trust between the various countries in SADC - each country is afraid of losing revenue. South Africa has been subject to various scams of products said to be destined for another country being re-routed within... There is much smuggling going on." [Logistics01]

"I don't have problems that they have rules and regulations to make sure that people don't cheat because they probably do cheat... SA cops are being told that some goods are being brought for repair and they are not coming back." [Logistics03]

The general dissatisfaction with dealing with customs at the border was not the end of the woes of transporting goods. There were police to deal with further along the road in various countries, as well as the cumbersome logistics of paying the penalties before the goods can continue their journey:

"Then you go into the SA roads, police must find fault with the truck. When fined I ask why can't I pay through internet? But they want somebody to drive from Botswana... with those rands in cash." [Manufacturer07]

"These Zimbabweans (drivers) are always arrested daily because of our weigh-bridge... the vehicle will take so many days at the border until our guy goes to Francistown and pay the fine." [Logistics06]

\section{Discretion and negotiation}

Given the discretionary powers of customs officials to decide on adequacy of compliance with myriad tariff codes and sometimes vague regulations, many respondents point to the potential risk:

"Botswana government is rotating customs staff at the borders to minimize possibility of corruption. Often the new customs staff at the borders are unfamiliar with procedures and codes.” [Retailer01] 
"The customs officers can sit on the documents for a long time... This breeds corruption as the clearing agents might be tempted to pay something in order for paper to be attended to immediately." [Logistics04]

The variation in application causes Botswana importersexporters to resort to negotiations with the customs personnel, which opens the possibility of financial inducements, especially in SADC or SACU countries other than South Africa:

"Tariff codes used are confusing. When we assign a code, one customs officer may agree with it while another may disagree at a later stage and the exporter would be penalized at this stage." [Manufacturer07]

"In other countries like Zambia and Mozambique it's even worse because even if you have the papers it's like you have broken the biggest law in their country. If you have money you can always move freely', [Logistics06]

\section{Circumvention and corruption}

Some respondents acknowledged the prevalence of corruption, but excused it in terms of economic conditions, and felt constrained to inform us of their firm's ethical policies for dealing with it:

"We said we do not believe in corruption and bribery... So we fall victims at the border here, instead of being processed... you leave here last. This just kills our whole logistic process.” \{Manufacturer07]

"Some of the Asian importers who go there [customs] and sort something out. Quite often we find that the Chinese importers can get something delivered in no time." [Logistics03]

"Actually most of the cases for bribery that side [Zimbabwe] is amongst the police. They are making many road blocks so that when you get there you give something." [Logistics05]

Other import-export firms were more pragmatic in their approach to the issue of corruption, seeing as an inevitable part of doing business in the region:

"When the driver leaves Durban he is given US $\$ 5,000 \ldots$...so he buys police on the road, he buys those people at the weighbridge who have to weigh the truck, and he 'buys' the customs office." [Wholesaler02]

"Most of them know the officers here and their phone numbers. They try to make an appointment in time and when they reach here then they don't have to wait but just shoot straight...” [Logistics05]

\section{Infrastructural deficiencies}

\section{Restricted border-times}

A consistent complaint by traders was the limited hours of operations at the border-posts, paperwork, and the nonavailability of customs staff to do on-site visits as required to seal containers at the factory or warehouse:

"When the truck is here, so we have to call customs and they will tell us they don't have transport, then we'll have somebody drive from here to there to pick them up." [Manufacturer03].

"If the inspection is booked for Saturday, then there are no facilities for documentation. With no documents you can't cross the border." [Manufacturer01]

"When the border is closed there is a long queue... Even if you have nothing to declare, you have to join the queue. Everyone has their own bundles - there is a lot of paperwork." [Wholesaler03]

The consequent delays at the border post are costly to the importers-exporters, not only in terms of the immediate shipment but for staying competitive in bidding for export opportunities:

"Everywhere in the world they receive sample in three days of request. Botswana it takes seven days because Friday or public holidays no courier works here because they can't get customs clearance." [Manufacturer01]

"Transport is costly and it means sending the products to Durban and sometimes missing the ship regularly or sending the products too early and no customs facility available on weekend or holiday." [Manufacturer05]

"Usually they collect everything in the afternoon, then overnight they drive to the border... Even though they are there at 8 o'clock or 6 o'clock they only see our goods around 12 or 11. ." [Wholesaler03].

\section{Inadequate ports}

The option of using the port of Walvis Bay in Namibia, where Botswana had leased part of the harbour for its exclusive use, did not meet with much enthusiasm from our respondents due to higher sea-freight cost and added on-the-road time and distance:

"Well, in terms of sea-freight the charges are more via Walvis Bay - the sea charges, not land charges. It is all related to volumes - more expensive for them to go into Walvis and unload a few containers." [Logistics03]

"Walvis Bay was initially seen as a threat by South Africa till they found that the volumes were much smaller. Using trucks to transfer shipments via the Trans-Kalahari Highway adds to cost." [Logistics01] 
"The land-freight is about the same cost from Walvis Bay. We use it on occasion where the goods are needed urgently but mainly from Europe - from other places you don't have that same saving." [Logistics03]

The establishment by Namibia of an inland 'dry-port' called Gabcon (Gaborone Container Port), for goods to be brought by rail to, had not proven a better substitute to clearing goods at any sea-port in the region. With delays in delivery and high costs involved it seems not to have been the boon to trade anticipated.

"The cost of transporting goods from Durban to Gabs (Gaborone) is huge; it is more than the cost of transporting goods from China to Durban." [Manufacturer02]

"And Gabcon is another story... your container can stay there up to thirty days." [Manufacturer04]

"If a private haulier is to collect the container, Gabcon will charge the same or even more as a penalty, a few pula more". [Logistics03]

\section{Transportation constraints}

Particularly as Botswana is landlocked, transportation to and from destinations in South Africa is a perennial challenge to exporters and importers, adding days if not weeks to the business schedule:

"Containers transferred by rail from Durban come on a South African train, then at the border the locomotive is changed to a Botswana one." [Logistics01]

"Some of the truckers are not happy to bring anything here because they say laws of Botswana are too hard - e.g. during holidays do not drive any commercial truck after 6pm." [Logistics06]

"Exports to Zambia through Kasungula Ferry faces a lot of delays. The ferry is allowed to take only one truck. As a result a truck may wait for a week before crossing." [Manufacturer07]

Typically the road conditions in Southern African are poor, not to mention the crossing of wild animals, causing lower speeds and greater truck maintenance:

"In Zambia there is also a bad road with pot holes so they opened another road and just gravelled it, so it's far better." [Wholesaler02]

"In Botswana... because game reserves are there, salt pans are there - so they can't build corridors and prevent animals from moving." [Retailer05]

"We did experience some breakdown... so it was there for almost the whole day, and because of the heat most of the leafy crops were gone..." [Wholesaler01].

\section{Security enroute}

Pilferage, stealing, robbery and hijacking are realities of transporting goods especially by road around Southern Africa especially if the goods can be easily re-sold:

"But for security reasons most will advise you to use rail, because on road transport anything can happen, it can be hijacked on transit...here and there in South Africa". [Logistics03]

"Some cars loaded on top of the ships instead of containers are at risk. Workers at the port of entry can have access and hence other car parts are often found missing." [Logistics04]

"We face minor security issues in RSA (like truck hijacking) because we are bringing in raw materials - not finished products - that can easily be sold." [Manufacturer07]

Generally the interview respondents seemed less aware of internal impediments to developing import or export opportunities, preferring to see the issue as one largely of external constraint. Nonetheless some of the respondents alluded to issues of operational complexity, market adaptation, price competitiveness and policy unknowns. As a whole these executives seemed to find domestic business sufficient for their scale of operations as well meeting some occasional unsolicited orders from around the region. There internal impediments to import-export by Botswana businesses will be explored in-depth in a subsequent publication.

\section{Inferences and implications}

\section{Theoretical contribution}

It has long been argued in various international fora such as WTO, the World Bank and the IMF that there would be much to be gained by converting existing NTBs into tariff-based protection (Centre for International Economics, 1999). There are several reasons why selective tariffication may arguably be considered preferable as a trade policy. First, with tariffs, unlike with most NTBs, the level of protection is transparent, with domestic producers able to know its duration and importers what their penalty will be. Second, revenue from tariffs goes to the government whereas proceeds from NTBs are either absorbed by higher costs of doing business. However based on research in Sub-Saharan Africa, Milward (2015) questions the 'Washington Concensus' orthodoxy of advocating free trade given the asymmetric levels of economic development among nations trading in the global market. Thus when tariffs are removed under economic integration treaties, they tend to be invariably replaced by NTBs to maintain similar protectionist goals against more developed economies, as is occurring in SADC and SACU. The present research suggests then that theories of economic integration need to be rethought in the context of regional groupings of developing countries of varying economic size and levels of development. 


\section{Policy consequences}

This research demonstrates that many of the prevalent NTBs within SADC and SACU are bureaucratic and infrastructural. The former are often opaque in that they are not formally stated in regulations; given rise to inconsistent decisions by officials in implementation. Apart from the imperative to streamline policy among Southern African countries, there is need to clarity regulations to reduce discretion at borders to a minimum thus limiting unintended trade-restriction. While it remains imperative for regional governments in any regional economic grouping in the developing and emergent world to have more equitable revenue sharing among members, harmonise technical standards, priority should be on initiatives to tackle administrative inefficiencies in licenses, duties and permits, as well as infrastructural upgrading of roads, ports, border posts, computerisation (Figure 3). Without these, all efforts to inculcate an export orientation in local industry through training and promotion in Botswana or any of the other small economies within the SADC or SACU regions would be quite premature and ineffectual.

Using theoretical models of comparative advantage, Venables (2003) demonstrates that economic integration between developing countries results in economic divergence among them and greater poverty to some members. So he advocates that they are better served by integration with developed countries which is an unlikely political outcome though inclusion of emerging economies are a reality in many regional groupings, as in the case of Southern Africa. Furthermore through pursuing economic treaties like the African Growth and Opportunity Act (AGOA) and the United Nations Conference on Trade and Development, Botswana would be able to benefit from preferential access to some developed markets in Europe, North America and Australasia. As such agreements are for a limited period, it is imperative that Botswana develop policies and establish programs to capitalize on these increasingly scarce opportunities to develop capacity rapidly.

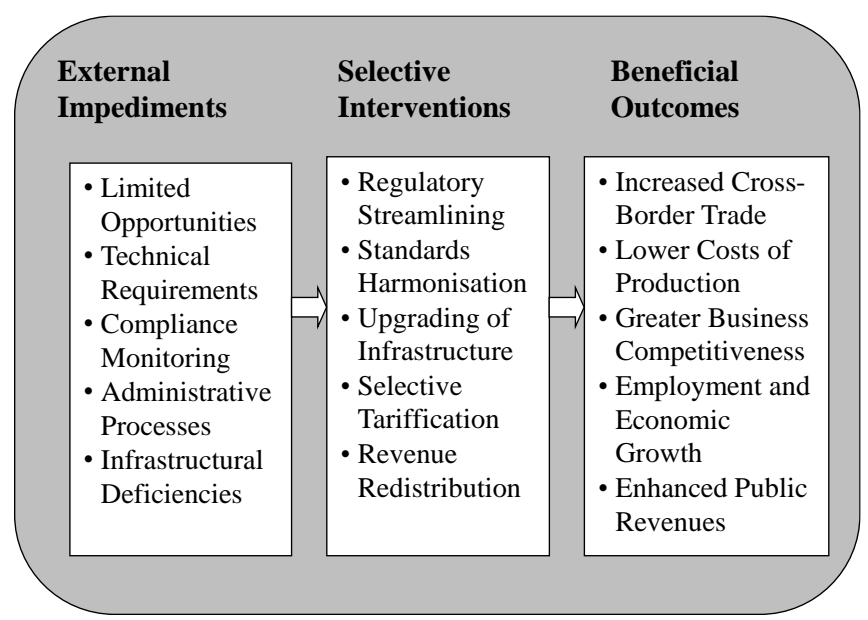

Figure 3: Southern African trade - challenges and prospects

\section{Concluding commentary}

The vision of enhancing trade within regions of Africa, if not the whole continent, for the achievement of economic prosperity is as venerable as the dreams of political independence from colonisation over a half-century now. Much is still blamed politically on the European colonial division of Africa, and yet these borders have been maintained by post-independence governments for the many decades since, to their short-term national revenue gain but long-term mutual economic detriment. Meanwhile borders have been removed as a barrier to trade between the former colonial countries presently in the European Union, which is the purported model for African economic integration and trade growth. To that end, it is imperative that developing countries, as in SADC or at least SACU, integrate their economies through reducing tariff and non-tariff barriers, to enable smaller members-states to produce tradable goods and services for an effective regional market. Established emergent economies may have had a head-start in exporting to global markets, yet smaller developing economies could well succeed within strategic segments of their regional markets, as a springboard to possible global competitiveness in niche markets.

\section{References}

Ali, M.Y. 1998. Managers' perceived barriers to export: a study of Australian small and medium-sized enterprises. [online] www/ANZMAC1998/CD_rom/ Ali43.pdf.

Azzi da Silva, P. \& da Rocha, A. 2001. 'Perception of export barriers to Mercosur by Brazilian firms', International Marketing Review, 18(6), 589-611.

Baldauf, A., Cravens, D.W. \& Wagner, U. 2000. 'Examining determinants of export performance in small open economies', Journal of World Business, 35(1), 61-79.

Central Statistical Office 2005. Exports by principle commodities. [online] www.CSO.gov.bw/ html/trade/tradec_tbl4.html.

Centre for International Economics 1999. Non-tariff barriers in Vietnam: A framework for developing a phase out strategy. [Report prepared for World Bank]. Canberra \& Sydney: Centre for International Economics.

Ching, S., Wong, C.Y.P., Zhang, A. 2004. 'Non-tariff barriers to trade in the Pacific Rim', Pacific Economic Review, 9(1): 65-73.

Dichtl, E, Koglmayr, H-G., Muller, S. 1990. 'International orientation as a precondition for export success', Journal of International Business Studies, 21 (Spring/Summer): 23-40.

Draper, P. \& Alves, P. (Eds.). 2009. Trade reform in Southern Africa: vision 2014? Johannesburg: Jacana Media.

Filmer, R. \& Mushiri, S. 2001. 'Customs revenue implications of the SADC Trade Protocol'. Paper prepared for the USAID/RCSA SADC Trade Protocol Project.

Gajdos, L. 2012. 'The EU automotive sector in a globalised market'. Policy Briefing European Parliament, Directorate-General for External Policies, [online] www.europarl.europa.eu/ RegData/ 
etudes/briefing_note/join/2012/491464/IPOL-INTA_SP(2012) 491464_EN.pdf.

Geda, A. \& Kebret, H. 2008. 'Regional economic integration in Africa: A review of problems and prospects with a case study of COMESA', Journal of African Economies, 17(3): 357-394.

Hasse. K. 2013. 'Non-tariff barriers choke African trade', Africa in Fact. 8: 5-8.

Katsikeas, C.S. \& Morgan, R.E. 1994. 'Differences in perceptions of exporting problems based on firm size and export market experience'. European Journal of Marketing, 28(5), 17-35.

Kee, H.L., Nicita, A. \& Olarreaga, M. 2009. 'Estimating trade restrictiveness indices', Economic Journal, 119: 534.

Kirk, R. \& Stern, M. 2005. 'The new Southern African customs union agreement', The World Economy, 28(2), 169-190.

Korth, C.M. 1991. 'Managerial barriers to U.S. exports', Business Horizons, March - April: 18-26.

Lages, L.F. 2000. 'A conceptual framework of the determinants of export performance: reorganizing key variables and shifting contingencies in export marketing', Journal of Global Marketing, 13(3), 29-51.

Leonidou, L.C. 1995. 'Export barriers: non-exporters perceptions', International Marketing Review, 12(1): 4-25.

Leonidou, L.C. 2004. 'An analysis of the barriers hindering small business export development. Journal of Small Business Management, 42(3): 279-302.

Limao, N. \& Venables, A.J. 2001. 'Infrastructure, geographical disadvantage, transport costs, and trade'. The World Bank Economic Review, 15(3), 451-479.

Longo, R. \& Sekkat, K. 2001. Obstacles to expanding intra-African trade. [OECD Technical Paper No.169]. Paris: Organisation for Economic Cooperation and Development.

McCarthy, C. 2003. 'The Southern African Customs Union in transition', African Affairs, 102(409), 605-630.

Malefane, M.R. \& Odhiambo, N.M. 2016. Evolution of trade policy in Botswana', Global Journal of Emerging Economies, 8(1), 22-34.

Marandu, E., Phambuka-Nsimbi, C. \& Thomas, A.O. 2012. 'Perceived prevalence of non-tariff barriers: A conceptual and empirical analysis', Journal of Global Business and Technology, 8(1): 16-36.

Milward, B. 2015. 'On the historical, moral and economic arguments for asymmetric trading regimes: The case of sub-Saharan Africa', World Economic Review, 2015(5).

Pasadilla, G.O. \& Liao, C.M. 2007. 'Non-tariff measures faced by Philippine agricultural exports in East Asia', Asian Journal of Agriculture and Development, 4(1): 115-138.

Robinson, P. 1996. 'Potential gains from infrastructural and national resource investment coordination in Africa'. In Teunissen, J.J. (Ed.) Regionalism and the Global Economy: The Case of Africa. The Hague: FONDAD.
Ronge, E. 2000. Trade within the COMESA and between the East African Community and the European Union. Nairobi: The Kenya Institute for Public Policy Research and Analysis (KIPPRA).

Rubin, H.J. \& Rubin, I.S. 2012. Qualitative interviewing: The art of hearing data. London: Sage Publications.

SADC 2014. 'Integration milestones'. Gaborone: Southern African Development Community. [online] URL: www.sadc.int/about-sadc.

Sazanami, Y., Shujiro, U. \& Kawai, H. 1995. Measuring the costs of protection in Japan. Washington, DC: Institute for International Economics.

Statistics Botswana 2014. Botswana international merchandise trade statistics No.2014/01. Statistics Botswana, Gaborone.

Thomas, D.R. 2006. 'A general inductive approach for analyzing qualitative evaluation data', American Journal of Evaluation, 27(2): 237-246.

Thompson, C.J. 1997. 'Interpreting consumers: A hermeneutical framework for deriving marketing insights from the texts of consumers' consumption stories', Journal of Marketing Research, 34(4): 438-455.

TIPS \& AusAid 2007. Intra-SADC trade performance review 2007. Pretoria: Trade \& Industrial Policy Strategies \& Canberra: AusAid.

Transparency International 2015. Corruption perceptions index 2015. [online] www.transparency.org/cpi2013/results.

Venables, A.J. 2003. 'Winners and losers from regional integration agreements', The Economic Journal, 113(490), 747-761.

Winkelmann, L \& Winkelmann, R, 1998. 'Tariffs, quotas and terms of trade: the case of New Zealand', Journal of International Economics, 46: 313-32.

World Economic Forum 2013. The global competitiveness report 2013-14. Geneva World Economic Forum. [online] www.intecap.edu.gt/oml/images/publicos/WEF_GlobalCompetitiv enessReport_2013-14.pdf.

Yang, Y.S., Leone, R.P. \& Alden, D.L. 1992. 'A market expansion ability approach to identify potential exporters', Journal of Marketing, 56: 84-96.

Yaprak, A. 1985. 'An empirical study of the differences between small exporting and non-exporting US firms', International Marketing Review, 2 (Summer): 72-83. 